Gadjah Mada International Journal of Business

January-April 2008, Vol. 10, No. 1, pp. 47-75

\title{
SHIFTS IN PATTERN OF SPECIALIZATION Case Studies of India and China
}

\author{
Tri Widodo*
}

This paper examines shifts in pattern of specialization of China's and India's exported groups of products defined in the three-digit Standard International Trade Classification (SITC) Revision 2. This paper applies Revealed Symmetric Comparative Advantages (RSCA) index and Spearman's rank correlation. Some conclusions are withdrawn. First, on average the comparative advantages of both China and India increase, except in the case of China for the period of 1998-2003. Second, China's pattern of comparative advantage changes more dynamically than that of India. Third, the China's and India's patterns of comparative advantage show different trends (divergent/more complementary).

Keywords: comparative advantages; correlation; revealed symmetric comparative advantage

JEL: F14; F17.

\section{*) Acknowledgement}

The author would like to thank Prof. Masumi Hakogi (HUE), Prof. Toshiyuki Mizoguchi (HUE) and Jeroen Hinloopen (University of Amsterdam) for the fruitful discussion. The author would also like to thank anonymous referee(s) for the valuable comments. 
Gadjah Mada International Journal of Business, January - April 2008, Vol. 10, No. 1

\section{Introduction}

China and India have performed a remarkable economic growth. Among countries with at least 10 million people in 2003, China and India have had a rapid economic growth since 1980 . From 1980-1990, China's Gross Domestic Product (GDP) grew on the average of 10.3 percent per year, while India's GDP grew on the average of 5.7 percent per year (World Bank 2006). The high rate of growth continued subsequently from 1990-2000 and 2000-2004. China's GDP grew on the average of 10.6 percent and 9.4 percent during the later two periods, respectively; meanwhile, India's GDP grew on the average of 6.0 percent and 6.2 percent, respectively. China's share in the global GDP increased significantly from 1.63 percent in 1990 to 4.68 percent in 2004, while India's share increased slightly from 1.46 percent in 1990 to only 1.67 percent in 2004. One of the explanatory reasons for the high growth is the increase in openness of the international trade policies conducted extensively by both China and India. Other reasons are the improvement of health and life expectancy, elevated labor force per capita due to the declining fertility rates and dependency ratios (Bloom et al. 2006).

China and India have significant roles in international trade and increasingly integrating themselves with the world economy. The World Trade Organization (WTO) (2005) notes that
China's share in the world merchandise export and import increased dramatically from 1.2 percent and 1.1 percent in 1983 to 6.7 percent and 6.1 percent in 2003, respectively. Meanwhile, India's share in the world merchandise export and import increased modestly from 0.5 percent and 0.7 percent in 1983 to 0.8 percent and 1.1 percent in 2003, respectively. An indicator commonly used to describe the integration level of a specific country is the share of export and import of goods and services in GDP formation. For both China and India, the share had roughly doubled for 1994-2004. China's share of export of goods and services increased from 18 percent in 1994 to 34 percent in 2004, while the India's share increased from 7 percent in 1983 to 19 percent in 2004. China's share of imports of goods and services in GDP increased from 16 percent in 1994 to 31 percent in 2004; meanwhile India's share increased from 9 percent in 1994 to 23 percent in 2004 (World Bank 2006).

China's and India's sustainable and high economic growth and intensive integration with the world economy have caused dramatic increases in the Asia's share of world exports and raw material consumption. In the case of China, this country has encouraged intra-regional trade in East Asia through the component and parts industry (Athukorala and Yamashita 2005; Ng and Yeats 2003). Urata (2006) finds that India's exports to East Asia and India's imports from 
East Asia increased from 22.3 percent for 1990-1994 to 23 percent for 20002004; and from 16.6 percent for 19901994 to 21.7 percent for 2000-2004, respectively. Given the large size of Chinese and Indian economies and their specific patterns of demand, the changes in their supply and demand structure have much larger impacts on the composition of world trade than those of the other late industrialized economies in Asia during their economic ascent(UNCTAD 2005). China and India are geographically large and neighboring emerging-market economies (EMEs), which are increasingly distinguished as two-up-and-coming economic powers (Das 2006). The impacts of China's growth on international product markets and global trade flows have been already apparent.

Given the strong integration with the world trade and their size of economy, it is interesting to analyze the shifts in the patterns of comparative advantages of China and India. This paper aims to answer some crucial questions. First, what sorts of exported groups of products in which China and India have comparative advantages? Second, how far have the patterns of comparative advantages of China and India shifted? Third, has the India's pattern of comparative advantages followed a sequence change in similar way to that of China? This paper is organized into several parts. Part 2 describes the literature review. Part 3 exhibits the methodology. Part 4 shows the calculation results and analysis. Finally, some conclusions and future implications are presented in Part 5.

\section{Literature Review}

Globalization, liberalization, economic integration, bilateral and multilateral trade agreements (BTA and MTA) have encouraged international strategic alliances conducted by countries. Trade liberalization not only offers opportunities for the export development but also carries more competitive environment in the international, regional and domestic markets. Parallel to the integration process in the world market, a critical issue on the country-specific specialization and the dynamic shifts in comparative advantage patterns emerges. Isogai et al. (2002), James and Movshuk (2003), Ng and Yeats (2003), Roland (2003), Hinloopen and Marrewijk (2001; 2004a; 2004b; 2004c), Batra and Khan (2005), and Wörz (2005) have examined the issue.

The issue of dynamic specialization and convergence of trade patterns are important to economic policy and to the countries' competitiveness for some reasons (Aiginger 1999). First, as far as the diversity of exported products is concerned, specializing only in limited groups of products might increase risks for the economy. If a country merely specializes in a limited numbers of exported products, the country might have some domestic problems when there are any international shocks 
in those products. For example, Indonesia, which had merely relied on its exports on oil, had fiscal problems in the early 1980s when the price of oil declined sharply since revenue from oil sectors is the main government revenue. Second, the economic integration can enhance efficiency and competitiveness because of the searching of countries' specialization, taking the advantage of scale economies, deepening the division of labors, decreasing in the transport costs, etc.

There are many researches analyzing the specialization and convergence of industrial structure. For example, Krugman (1991) finds that manufacturing is more regionally concentrated in the U.S. than in Europe. Some other researches are summarized in Table 1. Related to the issue of structural convergences across coun- tries and in parallel direction with the integration process in the world market, a crucial question on the dynamics of countries-specific specialization is arising: how far have the specialization and convergence of comparative advantage of India and China been going on? With many countries and industries, as well as the different initial distributions of exports and imports across countries and industries in the Asian region, different outcomes might be possible. Aiginger (1999) and Wörz (2005) state four possible combinations between the trade specialization and convergence in the trade patterns. All of which are depicted in Figure 1-i.e. more-specialized together with diverging in the trade patterns (Case1); less-specialized together with converging in the trade patterns (Case 2); more-specialized together with con-

\section{Figure 1. Four Possible Combinations: Specialization and Convergence}

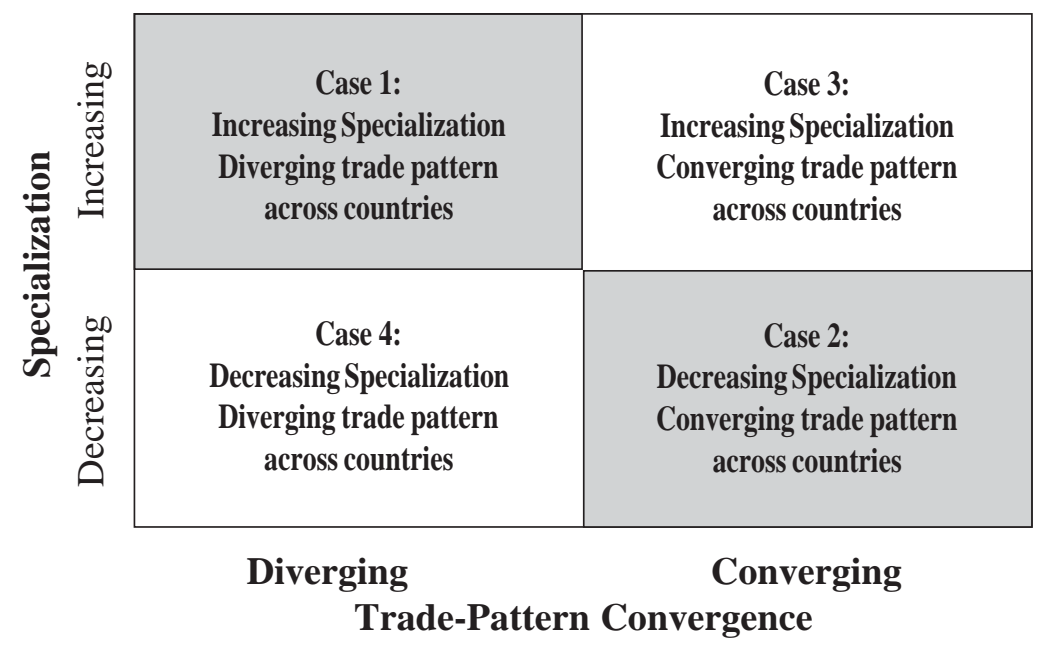

50 


\section{Tri Widodo-Shifts in Pattern of Specialization}

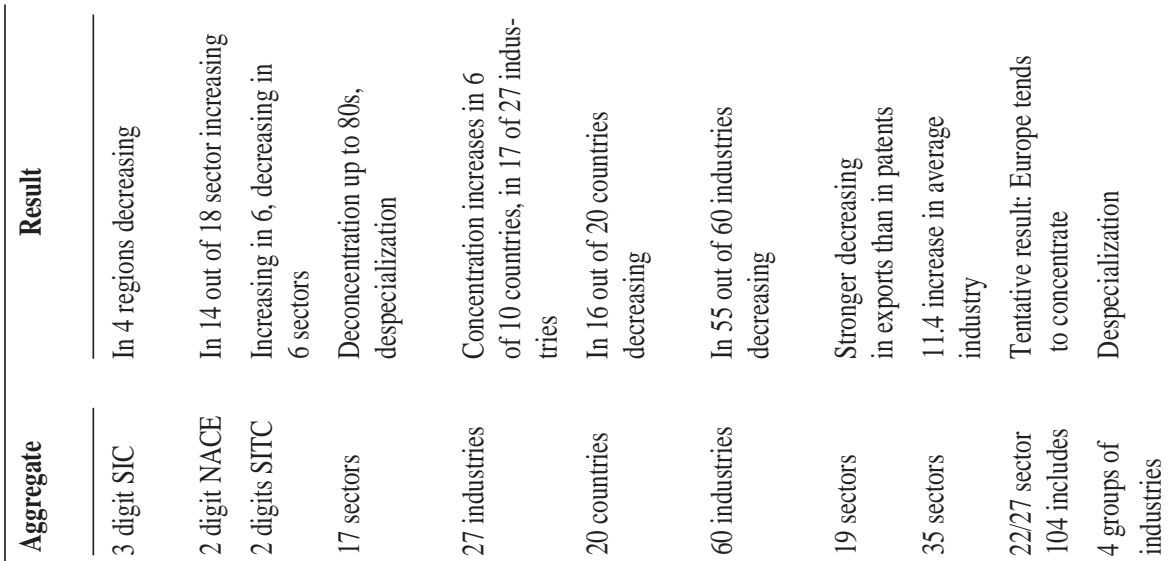

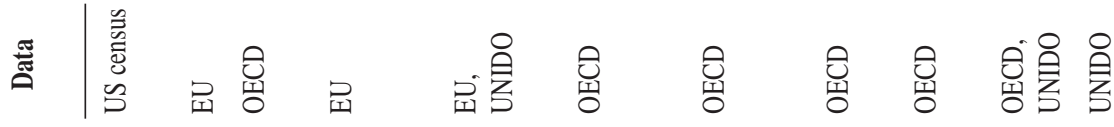

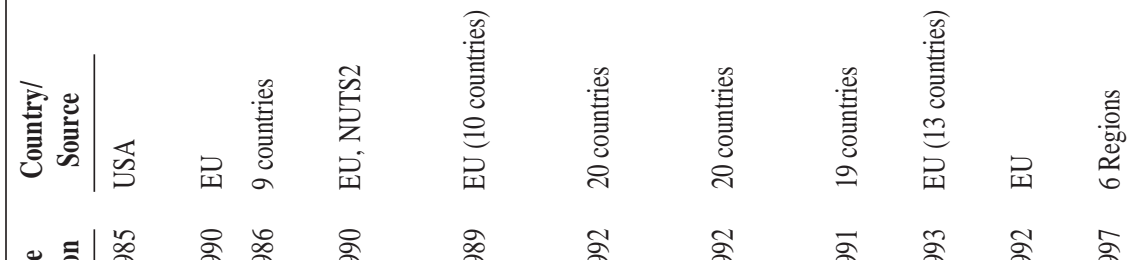

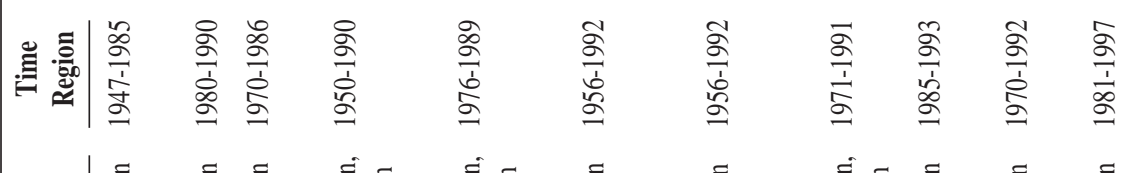

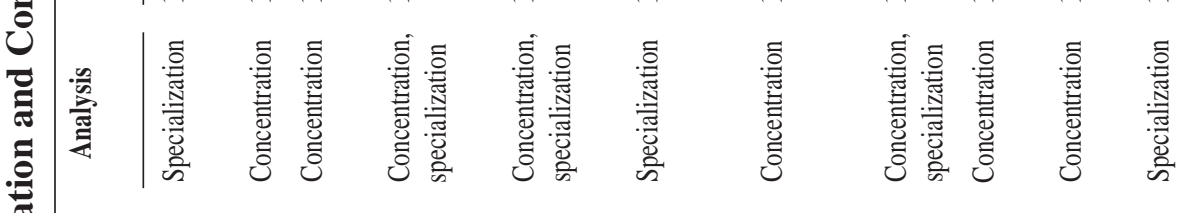

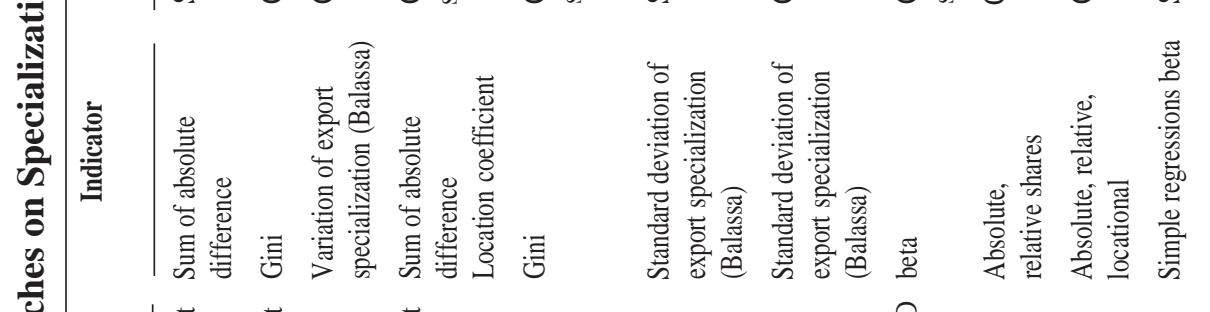

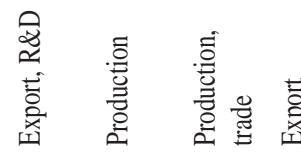


verging in the trade patterns (Case 3); and less-specialized together with diverging in the trade patterns (Case 4).

First, Case 1 takes place if countries in the region increasingly exploit their comparative advantages, and then reinforce their patterns of specialization accordingly. This is likely to happen if the specialization is mainly induced by the absolute advantages. For example, one country in the region exploits its oil as the main exported products; in contrast, the neighboring countries have no oil. This country then will have an increasing in its specialization and divergence in the trade patterns. Case 2 occurs in a parallel direction with the rising importance of intra-industry trade (IIT), ${ }^{1}$ and it is often observed for the homogenous trading partners in an advanced stage of development. Third, an example for Case 3 is that a dramatic increase in demand for computer equipments might cause specialization in the production of these products by countries that initially showed a weak specialization in different industries such as textiles, food, furniture, etc.
Fourth, Case 4 may happen, for example, if one furniture-producing country immediately shifts part of its production into the information and communications technologies sector, while another electronic producers move toward transportation sector. Which cases do China and India lay in- Cases $1,2,3$ or 4 ? Are they becoming less specialized or more specialized? Are their patterns of comparative advantage becoming more similar (convergent) or more different (divergent)?

\section{Methodology}

\section{Data}

This paper uses data on trade statistics published by the United Nations (UN), namely the International Trade Statistics Yearbook (ITSY) and the United Nations Commodity Trade Statistics Database (UN-COMTRADE). This paper uses 3-digit the Standard International Trade Classification (SITC) Revision 2. For comparison purposes, this paper focuses on 231 groups of products 3-digit SITC which

\footnotetext{
${ }^{1}$ IIT occurs when a country is both exporting and importing items in the same product classification category. In contrast, inter-industry trade happens when a country's exports and imports are in different classification category. Grubel and Lloyd (1975) mentioned several possible explanations for the occurrence of IIT, such as: product differentiation, transport costs, dynamic economies of scale, degree of product aggregation, differing income distribution in countries, and differing factor endowments and product variety.
} 
are covered in the ITSY $2003 .{ }^{2}$ Data on total world exports is obtained from the ITSY 1988, 1993, 1998 and 2003. Meanwhile, data on China's exports and India's exports are taken from the UN-COMTRADE.

\section{Revealed Symmetric Comparative Advantage (RSCA)}

There are many ways to scrutinize whether a country has comparative advantage for a specific product. One common method to determine how specialized a country in the production of a product is by calculating Revealed Comparative Advantage (RCA) index (Balassa 1965; 1979; 1986). ${ }^{2}$ The index examines the proportion of a good produced or exported. The formula to measure a country's RCA index is

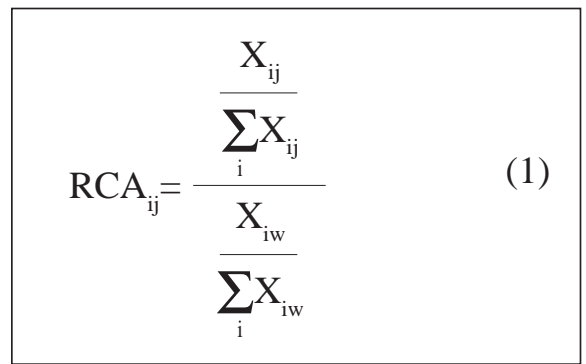

$\mathrm{RCA}_{\mathrm{ij}}=$ revealed comparative country $j$ for group of products (SITC) i

$\mathrm{x}_{\mathrm{ij}} \quad=$ export value of group of products $i$ by country $j$

$\sum_{\mathrm{i}} \mathrm{X}_{\mathrm{ij}}=$ total export value of country $j$

$\mathrm{x}_{\mathrm{iw}} \quad=$ export value of group of products $i$ of the world (w)

$\sum_{\mathrm{i}} \mathrm{X}_{\mathrm{i}}=$ total export value of the world (w) expressed as follows:

Where:

\footnotetext{
${ }^{2}$ There are some groups of products (SITC) are excluded from the analysis i.e Jute, raw or semiprocessed (SITC 264); Ores and concentrates of uranium and thorium (SITC 286); Electric current (SITC 351); Hoops and strip, of iron or steel, hot-rolled or cold rolled (SITC 675); Uranium depleted in U235 and thorium (including waste) and their alloys and articles thereof (SITC 688); Postal packages not classified according to kind (SITC 911); Postal packages not classified according to kind (SITC 961); Coins (other than gold coin), not being legal tender (SITC 961); and Gold, non-monetary excluding gold ores and concentrates (SITC 971). The exclusion is taken for some reasons. First, data on the world exports of those products is not reported in the ITSY. Some countries did not report their exports on those products and the others submitted the poor reports and insufficient explanation of estimates (UN, 1988-2005). Second, it is not realistic if there is a country exporting a product (SITC) but the world does have exports on it, whereas the country is a subset of the world. Third, the Revealed Symmetric Comparative Advantage Index employed in this paper is obviously not defined when there is no data on the world exports. As explained in the next subpart, the index is a ratio of a country's share of exports (numerator) and the world's share of exports (denominator). The ratio is not defined when the denominator is zero.

${ }^{3}$ See Balance et al. (1987) for a good discussion about indicators of comparative advantage.
} 
Gadjah Mada International Journal of Business, January - April 2008, Vol. 10, No. 1

The numerator represents the domestic percentage share of export value for a specific group of products $i$ in the domestic total export value. The denominator represents the world's percentage share of a specific group of products $i$ in the world total exports. The index, thus, contains a comparison of national export structure (the numerator) with the world export structure (the denominator). The values of the index are between zero and infinity $\left(0 \leq \mathrm{RCA}_{\mathrm{ij}} \leq \infty\right)$. The $R C A_{i j}$ greater than one implies that country $j$ has comparative advantage in group of products $i$. In contrast, the $R C A_{i j}$ less than one means that country $j$ has comparative disadvantage in group of products $i$. Since the RCA turns out to have values, which cannot be compared on both sides of one, the index is made into a symmetric index. The new index is called Revealed Symmetric Comparative Advantaged (RSCA) that is formulated as (Laursen 1998):

$$
\operatorname{RSCA}_{\mathrm{ij}}=\frac{\mathrm{RCA}_{\mathrm{ij}}-1}{\mathrm{RCA}_{\mathrm{ij}}+1}
$$

The $R S C A_{i j}$ index ranges from minus one to one (or $-1 \leq$ RSCA $_{\mathrm{iji}} \leq 1$ ). The interpretation of the RSCA is similar with that of the RCA. The RSCA greater than zero implies that country $j$ has comparative advantage in group of products $i$. In contrast, $R S C A_{i j}$ less than zero means that country $j$ has comparative disadvantage in group of products $i$.

\section{Correlation of Comparative Advantages}

This paper applies statistical hypothesis test procedure of correlation on the Revealed Symmetric Comparative Advantage (RSCA) to examine shifts in the pattern of comparative advantages. The degree of linear association between two series of RSCA can be compared by analyzing the Spearman's rank correlation coefficient that is given as follows (Gujarati 2000):

- Across periods (1988, 1993, 1998 and 2003):

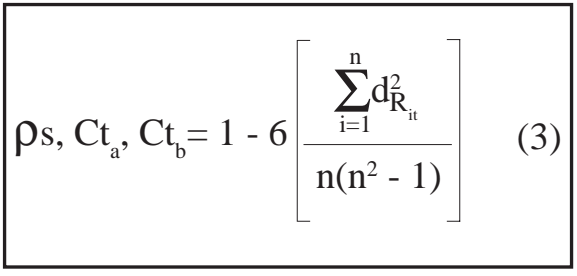

- Across countries (India and China):

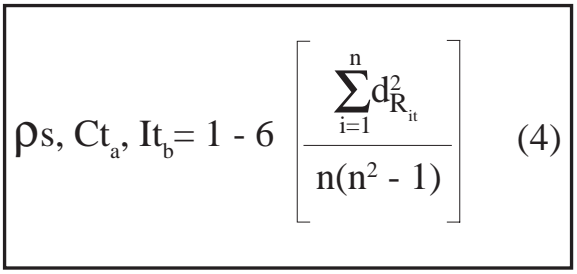

where:

$$
\begin{aligned}
\rho \mathrm{s}, \mathrm{Ct}_{\mathrm{a}}, \mathrm{Ct}_{\mathrm{b}}= & \text { the Spearman's rank } \\
& \text { correlation coefficient } \\
& \text { between China's } R S C A \\
& \text { at time } t_{a}\left(\text { symbol: } \mathrm{Ct} \mathrm{a}_{\mathrm{a}}\right) \\
& \text { and China's } R S C A \text { at } \\
& \text { time } t_{b}\left(\text { symbol: } \mathrm{Ct}_{\mathrm{b}}\right) . \\
\rho \mathrm{s}, \mathrm{Ct}_{\mathrm{a}}, \mathrm{It}_{\mathrm{b}}= & \text { the Spearman's rank } \\
& \text { correlation coefficient }
\end{aligned}
$$




$$
\begin{aligned}
& \text { between China's RSCA } \\
& \text { at time } t_{a} \text { (symbol: } \mathrm{Ct}_{\mathrm{a}} \text { ) } \\
& \text { and India's RSCA at } \\
& \text { time } t_{b} \text { (symbol: } \mathrm{It}_{\mathrm{b}} \text { ). } \\
& \mathrm{d}_{\mathrm{R}_{\mathrm{it}}}^{2} \quad=\left(\mathrm{R}_{\mathrm{RSCAiC}, \mathrm{t}_{\mathrm{a}}}-\mathrm{RS}_{\mathrm{RSCAiC}_{\mathrm{b}} \mathrm{t}_{\mathrm{b}}}\right)^{2} \\
& \text { for across periods. } \\
& \mathrm{d}_{\mathrm{R}_{\mathrm{it}}}^{2} \quad=\left(\mathrm{R}_{\mathrm{RSCA}_{\mathrm{iC}, \mathrm{t}}}-\mathrm{RS}_{\mathrm{RSCA}_{\mathrm{iI}, \mathrm{t}} \mathrm{t}_{\mathrm{b}}}\right. \\
& \text { for across countries. } \\
& \begin{array}{r}
\mathrm{R}_{\mathrm{RSCA}_{\mathrm{iC}, \mathrm{t}}}=\text { the rank of China's } \\
\text { RSCA of group of prod- }
\end{array} \\
& \text { ucts } i \text { at time } t_{a} \\
& \begin{array}{r}
\mathrm{R}_{\mathrm{RSCA} i \mathrm{iC} \mathrm{t}_{\mathrm{b}}}=\text { the rank of China's } \\
\text { RSCA of group of prod- }
\end{array} \\
& \text { ucts } i \text { at time } t_{b} \\
& \mathrm{R}_{\mathrm{RSCA}_{\text {iI, }} \mathrm{t}_{\mathrm{b}} \quad \begin{array}{r}
= \\
\text { of group of products } i \text { at }
\end{array}} \\
& \text { time } t_{b} \\
& \mathrm{n} \quad \text { is number of observa- } \\
& \text { tion groups of products } \\
& \text { (i.e. } 231 \text { SITC) } \\
& \mathrm{t}_{\mathrm{a}} \text { and } \mathrm{t}_{\mathrm{b}} \text { are years (1988, 1993, } \\
& 1998 \text { or 2003) }
\end{aligned}
$$

The values of Spearman's rank correlation coefficients range from minus one (a perfect negative linear relationship) and one (a perfect positive linear relationship). First, to analyze the dynamic shifts in the pattern of comparative advantages in India and China separately, the correlation coefficient across periods (Equation 3) is applied. The correlation coefficient closer to minus one (-1) implies that the shift in comparative advantages is 'more dynamic.' In contrast, the correlation coefficient closer to one (1) implies that the shift in comparative advantages is 'less dynamic.' Second, the correlation across countries, China and India, is also calculated (Equation 4). Higher and positive value of Spearman's rank correlation coefficient indicates more similar pattern of comparative advantage (competition) between the two countries. In contrast, lower and negative value of Spearman's rank coefficient implies stronger dissimilarity in the pattern of comparative advantages (complementary).

\section{Results and Analysis}

Internationally, traded products are classified according to the Standard International Trade Classification (SITC). There are nine headlines 1-digit in the SITC categories: 0 Food and live animals; 1 Beverage and tobacco; 3 Crude materials, inedible, except fuel; 3 Mineral fuels, lubricants and related materials; 4 Animal and vegetable oils, fats and waxes; 5 Chemical and related products nes.; 6 Manufacturing goods classified chiefly by material; 7 Machinery and transport equipment; 8 Miscellaneous manufactured articles; 9 Commodities and transaction not classified elsewhere.

It is possible to subdivide further these categories into their sub components: 2-digit SITC; 3-digit SITC; 4digit SITC and so on. These more detailed breakdowns are important, as there are a number of quite diverse categories within each of the broad SITC headings. 
Gadjah Mada International Journal of Business, January - April 2008, Vol. 10, No. 1

\section{Leading Exported Groups of Products}

The meaning of 'leading exported groups of products' can be seen from two different points of view. First, from the domestic point of view, the leading exported groups of products can be defined as groups of exported products that can yield bigger amount of foreign exchanges for the domestic economy. From this point of view, the higher share of a specific group of products in the total exports value, the bigger its contribution for the domestic economy will be. Table 2 represents the China's and India's ten exported groups of products with the biggest share in the total exports value in 1988 and 2003. By comparing groups of products in the top-ten list, it might be firmly stated that the leading exported groups of products of China were manufactures (1-digit SITC 7 and 8) meanwhile, those of India were varied (1-digit SITC 2,3,5,6 and 8) in 2003. In the case of China: automatic data process machines and units thereof (SITC 752); telecommunications equipment, nes, parts and accessories, nes (SITC 764); parts, nes of and accessories for machines of heading 751 or 752 (SITC 759); footwear (SITC 851); gramophones, dictating machines and other sound recorder (SITC 763); thermionic, microcircuits, transistors, valves, etc. (SITC 776) and electrical machinery and apparatus, nes (SITC 778) were the new groups of products listed in the top-ten products in 2003 since these products were not listed in the top-ten list in 1988. Meanwhile, the India's six new leading exported products in 2003 were gold, silver ware, jewelry and articles of precious materials, nes (SITC 897); medicinal and pharmaceutical products (SITC 541); textile yarn (SITC 851); under-garments, knitted or crocheted (SITC 856); made-up articles,

Table 2. Ten-Biggest Share in Total Domestic Exports, 1988 and 2003 (in \%)

\begin{tabular}{|c|c|c|c|}
\hline \multicolumn{4}{|c|}{ 1988-China } \\
\hline NO & SITC & Code Descriptions & Share \\
\hline 1 & 333 & Crude petroleum and oils obtained from bituminous minerals & 5.38 \\
\hline 2 & 845 & Outerwear knitted or crocheted, not elastic nor rubberized & 4.63 \\
\hline 3 & 931 & Special transactions, commodity not classified according to class & 4.62 \\
\hline 4 & 784 & Motor vehicle parts and accessories, nes & 4.23 \\
\hline 5 & 652 & Cotton fabrics, woven (not including narrow or special fabrics) & 3.49 \\
\hline 6 & 843 & Women, girls, infants outerwear, textile, not knitted or crocheted & 2.69 \\
\hline 7 & 894 & Baby carriages, toys, games and sporting goods & 2.65 \\
\hline 8 & 651 & Textile yarn & 2.56 \\
\hline 9 & 658 & Made-up articles, wholly or chiefly or textile materials, nes & 2.49 \\
\hline 10 & 654 & Textile fabrics, woven, other than cotton or man-made fibres & 2.01 \\
\hline
\end{tabular}


Tri Widodo-Shifts in Pattern of Specialization

Continued from Table 2

\begin{tabular}{|c|c|c|c|}
\hline \multicolumn{4}{|c|}{ 1988-India } \\
\hline NO & $\underline{\text { SITC }}$ & Code Descriptions & Share \\
\hline 1 & 667 & Pearls, precious and semi-precious stones, unworked or worked & 20.82 \\
\hline 2 & 843 & Women, girls, infants outerwear, textile, not knitted or crocheted & 4.78 \\
\hline 3 & 652 & Cotton fabrics, woven (not including narrow or special fabrics) & 3.38 \\
\hline 4 & 611 & Leather & 3.36 \\
\hline 5 & 281 & Iron ore and concentrates & 3.33 \\
\hline 6 & 074 & Tea and mate & 2.98 \\
\hline 7 & 659 & Floor coverings, etc & 2.97 \\
\hline 8 & 036 & Crustaceans and molluscs, fresh, chilled, frozen, salted, etc & 2.85 \\
\hline 9 & 334 & Petroleum products, refined & 2.50 \\
\hline 10 & 612 & Manufactures of leather or of composition leather, nes; etc & 2.23 \\
\hline \multicolumn{4}{|c|}{ 2003-China } \\
\hline 1 & $752^{\#}$ & Automatic data process machines and units thereof & 9.36 \\
\hline 2 & $764^{\#}$ & Telecommunications equipment, nes; parts and accessories, nes & 6.34 \\
\hline 3 & $759^{\#}$ & Parts, nes of and accessories for machines of heading 751 or 752 & 4.37 \\
\hline 4 & 894 & Baby carriages, toys, games and sporting goods & 3.28 \\
\hline 5 & 845 & Outerwear knitted or crocheted, not elastic nor rubberized & 3.24 \\
\hline 6 & $851^{\#}$ & Footwear & 2.85 \\
\hline 7 & 843 & Women, girls, infants outerwear, textile, not knitted or crocheted & 2.80 \\
\hline 8 & $763^{\#}$ & Gramophones, dictating machines and other sound recorder & 2.40 \\
\hline 9 & $776^{\#}$ & Thermionic, microcircuits, transistors, valves, etc. & 2.37 \\
\hline 10 & $778^{\#}$ & Electrical machinery and apparatus, nes & 2.31 \\
\hline
\end{tabular}

\section{3-India}

1667 Pearls, precious and semi-precious stones, unworked or worked 13.35

2334 Petroleum products, refined $\quad 5.47$

$3 \quad 897^{\#}$ Gold, silver ware, jewelry and articles of precious materials, nes 3.45

$4 \quad 541^{\#} \quad$ Medicinal and pharmaceutical products 3.21

$5 \quad 651^{\#} \quad$ Textile yarn 3.09

6843 Women, girls, infants outerwear, textile, not knitted or crocheted 3.07

$7 \quad 846^{\#} \quad$ Under-garments, knitted or crocheted 2.73

$8 \quad 658^{\#} \quad$ Made-up articles, wholly or chiefly or textile materials, nes $\quad 2.52$

$9 \quad 674^{\#} \quad$ Universals, plates, and sheets, of iron or steel 1.84

10281 Iron ore and concentrates 1.76

Note: * means new product in 2003, which not listed in ten-biggest share in 1988

Source: The ITSY and UN-COMTRADE (author's calculation). 
wholly or chiefly or textile materials, nes (SITC 658) and iron ore and concentrates (SITC 674).

Second, from the international competition point of view, leading exported groups of products can be defined as groups of products that can compete internationally. A specific exported group of products becomes leading exported group if its share in the total world export value is relatively dominant. It might be possible that a specific group of products is not significant as a foreign exchange creator but it can compete internationally. Table 3 represents the China's and
India's ten exported groups of products with the biggest share in total world exports. China, historically, is famous as silk-producer. China's share of export on silk (SITC 261) covered 51.75 percent of the total world silk export in 1988 and it became 77.19 percent in 2003. Silk still became the first leading exported products for China in 1988 and 2003 in term of international competition. The other leading exports in 1988 -except for made-up articles, wholly or chiefly or textile materials, nes (SITC 658)- had been replaced by new leading exported groups of products in 2003. In term of

Table 3. Ten-Biggest Share in Total World Exports, 1988 and 2003 (in \%)

\begin{tabular}{|c|c|c|c|}
\hline \multicolumn{4}{|c|}{ 1988-China } \\
\hline NO & SITC & Code Descriptions & Share \\
\hline 1 & 261 & Silk & 51.75 \\
\hline 2 & 572 & Explosives and pyrotechnic products 28.8 & \\
\hline 3 & 3658 & Made-up articles, wholly or chiefly or textile materials, nes & 22.81 \\
\hline 4 & 074 & Tea and mate & 22.25 \\
\hline 5 & 291 & Crude animal materials, nes & 20.90 \\
\hline 6 & 654 & Textile fabrics, woven, other than cotton or man-made fibres & 17.14 \\
\hline 7 & 652 & Cotton fabrics, woven (not including narrow or special fabrics) & 15.84 \\
\hline 8 & 847 & Clothing accessories, or textile fabrics, nes & 14.97 \\
\hline 9 & 056 & Vegetables, roots and tubers, prepared or preserved, nes & 13.33 \\
\hline 10 & 689 & Miscellaneous non-ferrous base metals, employed in metallurgy & 13.23 \\
\hline \multicolumn{4}{|c|}{ 1988-India } \\
\hline 1 & 074 & Tea and mate & 22.88 \\
\hline 2 & 612 & Manufactures of leather or of composition leather, nes; etc & 15.55 \\
\hline 3 & 667 & Pearls, precious and semi-precious stones, unworked or worked & 12.47 \\
\hline 4 & 075 & Spices & 10.86 \\
\hline 5 & 042 & Rice & 8.56 \\
\hline 6 & 659 & Floor coverings, etc. & 6.25 \\
\hline 7 & 611 & Leather & 6.17 \\
\hline 8 & 281 & Iron ore and concentrates & 5.71 \\
\hline 9 & 844 & Under garments of textile fabrics, not knitted or crocheted & 5.54 \\
\hline 10 & 273 & Stone, sand and gravel & 4.61 \\
\hline
\end{tabular}


Tri Widodo-Shifts in Pattern of Specialization

Continued from Table 3

\begin{tabular}{|c|c|c|c|}
\hline \multicolumn{4}{|c|}{ 2003-China } \\
\hline NO & SITC & Code Descriptions & Share \\
\hline 1 & 261 & Silk & 77.19 \\
\hline 2 & $323^{\#}$ & Briquettes, coke and semi-coke; lignite or peat; retort carbon & 46.18 \\
\hline 3 & $411^{\#}$ & Animal oils and fats & 38.95 \\
\hline 4 & $848^{\#}$ & Articles or apparel, clothing accessories, non-textile, headgear & 37.02 \\
\hline 5 & $666^{\#}$ & Pottery & 30.36 \\
\hline 6 & $786^{\#}$ & Trailers, and other vehicles, not motorized, nes & 29.62 \\
\hline 7 & $831^{\#}$ & Travel goods, handbags etc, of leather, plastics, textile, others & 28.74 \\
\hline 8 & $894^{\#}$ & Baby carriages, toys, games and sporting goods & 27.11 \\
\hline 9 & 658 & Made-up articles, wholly or chiefly or textile materials, nes & 26.27 \\
\hline 10 & $851^{\#}$ & Footwear & 26.13 \\
\hline \multicolumn{4}{|c|}{ 2003-India } \\
\hline 1 & $667^{\#}$ & Pearls, precious and semi-precious stones, unworked or worked & 13.91 \\
\hline 2 & 042 & Rice & 12.46 \\
\hline 3 & $074^{\#}$ & Tea and mate & 10.85 \\
\hline 4 & 281 & Iron ore and concentrates & 9.54 \\
\hline 5 & 075 & Spices & 8.32 \\
\hline 6 & $897^{\#}$ & Gold, silver ware, jewelry and articles of precious materials, nes & 7.46 \\
\hline 7 & 659 & Floor coverings, etc. & 7.30 \\
\hline 8 & 273 & Stone, sand and gravel & 7.25 \\
\hline 9 & $658^{\#}$ & Made-up articles, wholly or chiefly or textile materials, nes & 6.81 \\
\hline 10 & $697^{\#}$ & Household equipment of base metal, nes & 6.62 \\
\hline
\end{tabular}

Note: \# means new product in 2003, which not listed in ten-biggest share in 1988

Source: The ITSY and UN-COMTRADE (author's calculation).

kinds of exported groups of products, it might be said that the top-ten China's exports were dominated by manufacturing sector (1 digit SITC 7 and 8). Meanwhile the top-ten India's exports were slightly dominated by primary products (1-digit SITC 0 and 2).

\section{Shifts in the Pattern of Comparative Advantages}

The countries' comparative advantages are not static but dynamic. Theoretically, specialization based on comparative advantage under free trade changes the (endogenous) rate of productivity growth in sectors in the economies. Productivity levels determine comparative advantage and affect the allocation of labor (resources) between sectors in the economies. This sequentially determines relative rates of productivity growth, and thereby feeds back to shape the evolution of productivity levels over time. In this way, current comparative advantage is endogenously determined. 
Considering comparative advantage in the models of economic growth and trade has led a number of authors to speak in term of 'dynamic comparative advantage’. Redding (2004) notes that comparative advantage is endogenously determined by past technological change, while simultaneously shaping current rates of innovation. The dynamic of comparative advantage might be caused by the role of input trade (Jones 2000); friction in international trade and investment flows due to geography, institutions, transport, and information cost (Venables 2001); the transmission of knowledge across borders (Grossman and Helpman 1991); technological differences across border (Trefler 1995) and monopolistic competition in differentiated products with increasing return to scale (Krugman 1979).

China and India are believed to have different dynamics in their comparative advantage. The rapid growth in the exports of manufactured goods is the cause of countries' comparative advantage. Martin and Manole (2004) find that there are significant differences of export growth in low-technology products, medium-technology products and high-technology products between China and India for the period 1981-2001. Table 4 shows the China and India's top-ten groups of products with the highest RSCA index in 1988 and 2003. In term of the number of newcomers in the top-ten list 2003, China and India had eight and three new products listed in 2003, respectively. In the top-ten groups, the shift of comparative advantages of China had been more dynamic than that of India. If we compare the value of the RSCA index, the India's RSCA indexes of the top-ten groups of products are much higher than the China's ones. In 2003, the India's RSCA indexes of the top-ten products ranged from 0.770 to 0.883 ; meanwhile, the China's RSCA indexes of the top-ten products ranged from 0.627 to 0.856 .

Table 4. Ten-Highest Revealed Symmetric Comparative Advantages, 1988 and 2003

\begin{tabular}{|c|c|c|c|}
\hline \multicolumn{4}{|c|}{ 1988-China: } \\
\hline NO & SITC & Code Descriptions & RSCA \\
\hline 1 & 261 & Silk & 0.928 \\
\hline 2 & 572 & Explosives and pyrotechnic products & 0.875 \\
\hline 3 & 658 & Made-up articles, wholly or chiefly or textile materials, nes & 0.845 \\
\hline 4 & 074 & Tea and mate & 0.841 \\
\hline 5 & 291 & Crude animal materials, nes & 0.832 \\
\hline 6 & 654 & Textile fabrics, woven, other than cotton or man-made fibres & 0.798 \\
\hline 7 & 652 & Cotton fabrics, woven (not including narrow or special fabrics) & 0.783 \\
\hline 8 & 847 & Clothing accessories, or textile fabrics, nes & 0.772 \\
\hline 9 & 056 & Vegetables, roots and tubers, prepared or preserved, nes & 0.748 \\
\hline 10 & 689 & Miscellaneous non-ferrous base metals, employed in metallurgy & 0.746 \\
\hline
\end{tabular}


Tri Widodo-Shifts in Pattern of Specialization

Continued from Table 4

\begin{tabular}{|c|c|c|c|}
\hline \\
\hline \multicolumn{3}{|c|}{$\begin{array}{l}\text { 1988-India: } \\
\text { NO SITC }\end{array}$} & RSCA \\
\hline 1 & 074 & Tea and mate & 0.952 \\
\hline 2 & 612 & Manufactures of leather or of composition leather, nes; etc & 0.930 \\
\hline 3 & 667 & Pearls, precious and semi-precious stones, unworked or worked & 0.914 \\
\hline 4 & 075 & Spices & 0.902 \\
\hline 5 & 042 & Rice & 0.877 \\
\hline 6 & 659 & Floor coverings, etc. & 0.835 \\
\hline 7 & 611 & Leather & 0.833 \\
\hline 8 & 281 & Iron ore and concentrates & 0.821 \\
\hline 9 & 844 & Under garments of textile fabrics, not knitted or crocheted & 0.816 \\
\hline 10 & 273 & Stone, sand and grave & 0.783 \\
\hline
\end{tabular}

\section{3-China:}

$\begin{array}{llll}1 & 261 & \text { Silk } & 0.856 \\ 2 & 323^{\#} & \text { Briquettes, coke and semi-coke; lignite or peat; retort carbon } & 0.771 \\ 3 & 411^{\#} & \text { Animal oils and fats } & 0.734 \\ 4 & 848^{\#} & \text { Articles or apparel, clothing accessories, non-textile, headgear } & 0.722 \\ 5 & 666^{\#} & \text { Pottery } & 0.671 \\ 6 & 786^{\#} & \text { Trailers, and other vehicles, not motorized, nes } & 0.664 \\ 7 & 831^{\#} & \text { Travel goods, handbags etc, of leather, plastics, textile, others } & 0.655 \\ 8 & 894^{\#} & \text { Baby carriages, toys, games and sporting goods } & 0.638 \\ 9 & 658 & \text { Made-up articles, wholly or chiefly or textile materials, nes } & 0.629 \\ 10 & 851^{\#} & \text { Footwear } & 0.627\end{array}$

\section{3-India:}

\begin{tabular}{llll}
1 & 667 & Pearls, precious and semi-precious stones, unworked or worked & 0.883 \\
2 & 042 & Rice & 0.871 \\
3 & 074 & Tea and mate & 0.853 \\
4 & 281 & Iron ore and concentrates & 0.834 \\
5 & 075 & Spices & 0.812 \\
6 & $897^{\#}$ & Gold, silver ware, jewelry and articles of precious materials, nes & 0.793 \\
7 & 659 & Floor coverings, etc. & 0.789 \\
8 & 273 & Stone, sand and gravel & 0.788 \\
9 & $658^{\#}$ & Made-up articles, wholly or chiefly or textile materials, nes & 0.775 \\
10 & $697^{\#}$ & Household equipment of base metal, nes & 0.770 \\
\hline
\end{tabular}

Note: \# means new product in 2003, which not listed in ten-biggest share in 1988

Source: The ITSY and UN-COMTRADE (author's calculation). 
Gadjah Mada International Journal of Business, January - April 2008, Vol. 10, No. 1

Table 4 only shows structural change in the pattern of comparative advantages within the top-ten list. The next question is about how is the general structural change of comparative advantages? It is not confirmed that there is a structural change in the pattern of comparative advantages by only looking at the comparative advantages within the top-ten. This paper applies the Spearman's rank correlations on RSCA across periods (1988, 1993, 1998 and 2003) to separately scrutinize the structural change of China and India's patterns of comparative advantages (as described in equation 3 in the case of China, similar logic is also applied for India). Table 5 represents Spearman's rank correlation coeffi- cients, which are statistically significant at 1 percent level of significance. ${ }^{4}$ It is clearly shown that China had smaller coefficients of the Spearman's rank correlation than those of India for any paired-times. For example, the coefficient for the China's comparative advantage in 1988 and in 2003 was 0.515 , meanwhile the India's one was 0.683. Therefore, it implies that there were structural changes in the comparative advantage of China and India. In addition, since the China's rank correlations were smaller than the India's, it can be firmly stated that the structural changes in the China's pattern of comparative advantages were more dynamic than those in the India's do for 1988-2003.

Table 5. Spearman Rank Correlation

\begin{tabular}{|c|c|c|c|c|c|c|c|c|c|c|c|}
\hline & & & Chir & & & & & & India & & \\
\hline & Chir & na's Cc & mpara & ve Adv & ntages & & Indi & s Com & arativ & Advar & ages \\
\hline & & 1988 & 1993 & 1998 & 2003 & & & 1988 & 1993 & 1998 & 2003 \\
\hline & 1988 & 1.000 & $.779 *$ & $.641^{*}$ & $.515^{*}$ & & 1988 & 1.000 & $.858 *$ & $.831 *$ & $.683^{*}$ \\
\hline 言 兽 & 1993 & $.779 *$ & 1.000 & $.854 *$ & $.757 *$ & 芯 & 1993 & $.858 *$ & 1.000 & $.923^{*}$ & $.822 *$ \\
\hline ๓ & 1998 & $.641 *$ & $.854^{*}$ & 1.000 & $.881^{*}$ & (⿻) & 1998 & $.831^{*}$ & $.923 *$ & 1.000 & $.855^{*}$ \\
\hline & 2003 & $.515^{*}$ & $.757 *$ & $.881^{*}$ & 1.000 & 匽 & 2003 & $.683 *$ & $.822 *$ & $.855^{*}$ & 1.000 \\
\hline
\end{tabular}

Note: * Correlation is significant at the 0.01 level (2-tailed).

Source: The ITSY and UN-COMTRADE (author's calculation).

\footnotetext{
${ }^{4}$ Discussion with Jeroen Hinloopen (Department of Economics, University of Amsterdam) confirms that the Spearman's rank correlation can be used to examine the shift in pattern of comparative advantage. However, we will face some difficulties in the inferential statistics. Hinllopen and Marrewijk (2001; 2004a; 2004b; 2004c) proposed some supplemental quantitative measures other than the commonly used statistical methods i.e. mobility indicator associated with Markov transition matrices, Galtonian regressions, probability-probability (p-p) plots and the Harmonic Mass index. However, the author would argue that these measures are also still lag of the inferential statistics.
}

62 
Exports structure as well as the path and prospects of economic development in a country are likely to be closely related. The country might have a linear structural change in the economic development starting from agricultural sector basis to manufacturing sector basis and even further to service sector basis subsequently (Todaro 2000). As far as the patterns of comparative advantage are concerned, it might be argued that the advanced countries will have a less dynamic structural change in their comparative advantage due to the domestic full employment if it is compared with that of the less developed countries. Hence, the comparative advantage and steadiness of the pattern seem to be in the parallel direction with the prosperous development(Wörz 2005). As emerging countries, it is theoretically believed that China and India will try to raise their comparative advantages and to specialize in products with higher comparative advantages.
Table 6 shows the statistics of China's and India's RSCA index, including mean, median, standard deviation, coefficient of variation and skewness. Meanwhile, Table 7 summarizes statistical tests on the difference of means across periods. In the case of India, the increases in averages of comparative advantages are statistically significant at 1 percent level of significance.

Meanwhile in the case of China, although there is an increase in the average of comparative advantages in 1993 and 1998, the increase is statistically insignificant. By similarly comparing the average comparative advantages in 1993 and 2003, there is an increase in the comparative advantages but the increase is statistically insignificant. From this statistic test, it can be noted that India has a steady and significant increase in the average of comparative advantage for 1988-2003. China has a significant increase for 1988-1993 and a significant decrease for 1998-2003.

Table 6. Statistics of Revealed Symmetric Comparative Advantage

\begin{tabular}{|c|c|c|c|c|c|c|c|c|}
\hline \multirow[b]{2}{*}{ Statistics } & \multicolumn{4}{|c|}{ China } & \multicolumn{4}{|c|}{ India } \\
\hline & 1988 & 1993 & 1998 & 2003 & 1988 & 1993 & 1998 & 2003 \\
\hline Mean & $-\overline{-0.254}$ & $-\overline{-0.178}$ & $\overline{-0.163}$ & $\overline{-0.193}$ & $-\overline{-0.429}$ & -0.375 & -0.338 & -0.217 \\
\hline Median & -0.404 & -0.220 & -0.175 & -0.210 & -0.621 & -0.562 & -0.531 & -0.315 \\
\hline Standard Deviation & 0.567 & 0.540 & 0.528 & 0.513 & 0.569 & 0.567 & 0.570 & 0.541 \\
\hline Coefficient of Variat & tion-2.237 & 7-3.032 & -3.233 & -2.664 & -1.325 & -1.512 & -1.688 & -2.488 \\
\hline Skewness & 0.399 & 0.141 & 0.118 & 0.087 & 0.920 & 0.737 & 0.675 & 0.340 \\
\hline
\end{tabular}

Source: The ITSY and UN-COMTRADE (author's calculation). 
Gadjah Mada International Journal of Business, January - April 2008, Vol. 10, No. 1

Table 7. Test of Means Difference of RSCA

\begin{tabular}{|c|c|c|}
\hline $\begin{array}{c}\text { Difference between means } \\
\text { of Comparative Advantages } \\
\text { in }\end{array}$ & t-statistics & Sig. (2-tailed) \\
\hline \multicolumn{3}{|l|}{ China } \\
\hline 1988 and 1993 & $-3.086 *$ & .002 \\
\hline 1993 and 1998 & -.785 & .434 \\
\hline 1998 and 2003 & $1.779 * * *$ & .077 \\
\hline \multicolumn{3}{|l|}{ India } \\
\hline 1988 and 1993 & $-3.073 *$ & .002 \\
\hline 1993 and 1998 & $-2.720 *$ & .007 \\
\hline 1998 and 2003 & $-6.439 *$ & .000 \\
\hline
\end{tabular}

Notes: *, **, *** is significant at the $0.01,0.05$ and 0.1 levels (2-tailed), respectively.

Source: The ITSY and UN-COMTRADE, author's calculation.

Figure 2 shows the distribution of China's and India's comparative advantages and comparative advantages in 1988, 1993, and 2003. The asymmetric distribution of both countries' comparative advantage can be clearly identified. Skewness coefficients of the distribution are positive (Table 6). They imply that China and India become concentrated in products with lower comparative advantage in 1988. It can be seen clearly in 1988 from the high frequency of products with low level of comparative advantages in both China and India. It is interesting to compare the shift of patterns of comparative advantages. The distribution of China's comparative advantages shifts quickly to become more specialized on the higher comparative advantage products (shown by smaller skewness) in 1988-1993, but it is slow in 1993-2003. In contrast, the distribution of the India's comparative advantages shifts slowly to become more specialized on the higher comparative advantage products (shown by smaller skewness) in 1988-1998, but it is quick in 1993-2003. 


\section{Tri Widodo-Shifts in Pattern of Specialization}

Figure 2. Distribution of Comparative Advantages (China)

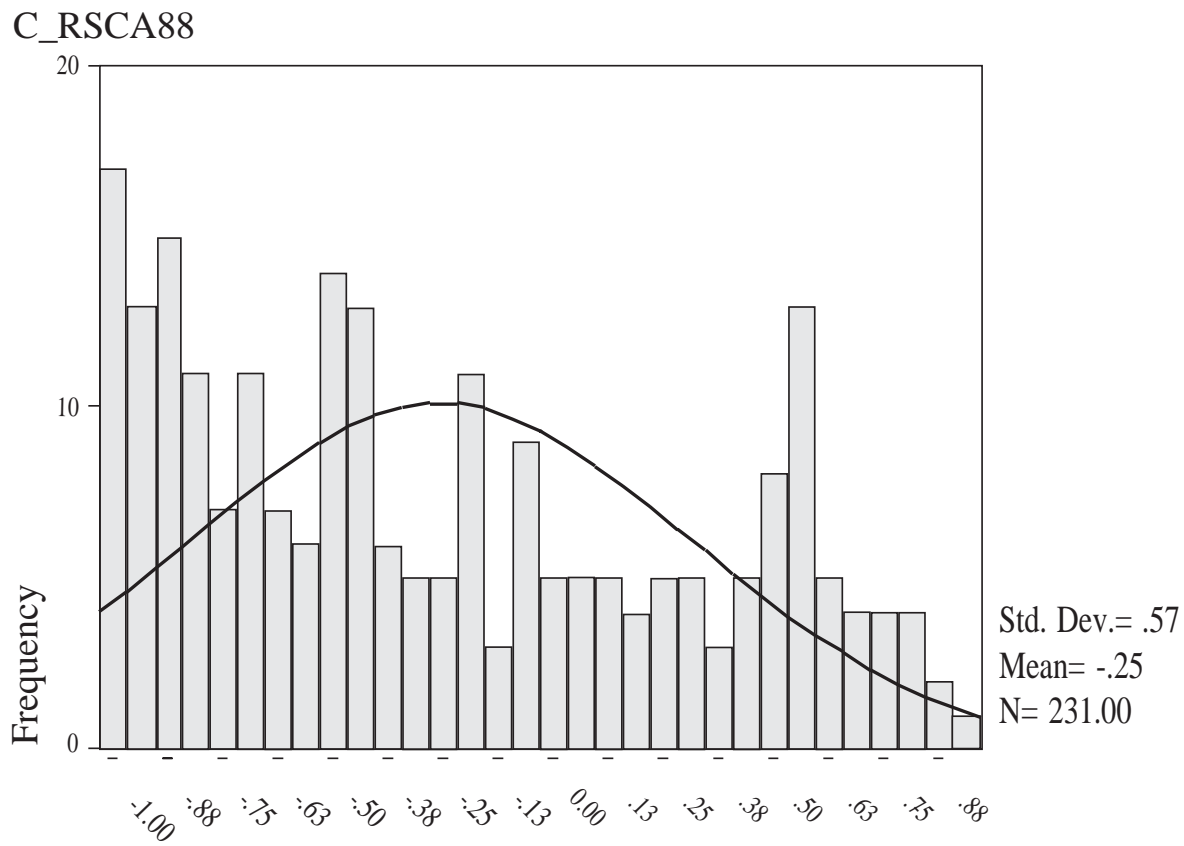

C_RSCA93

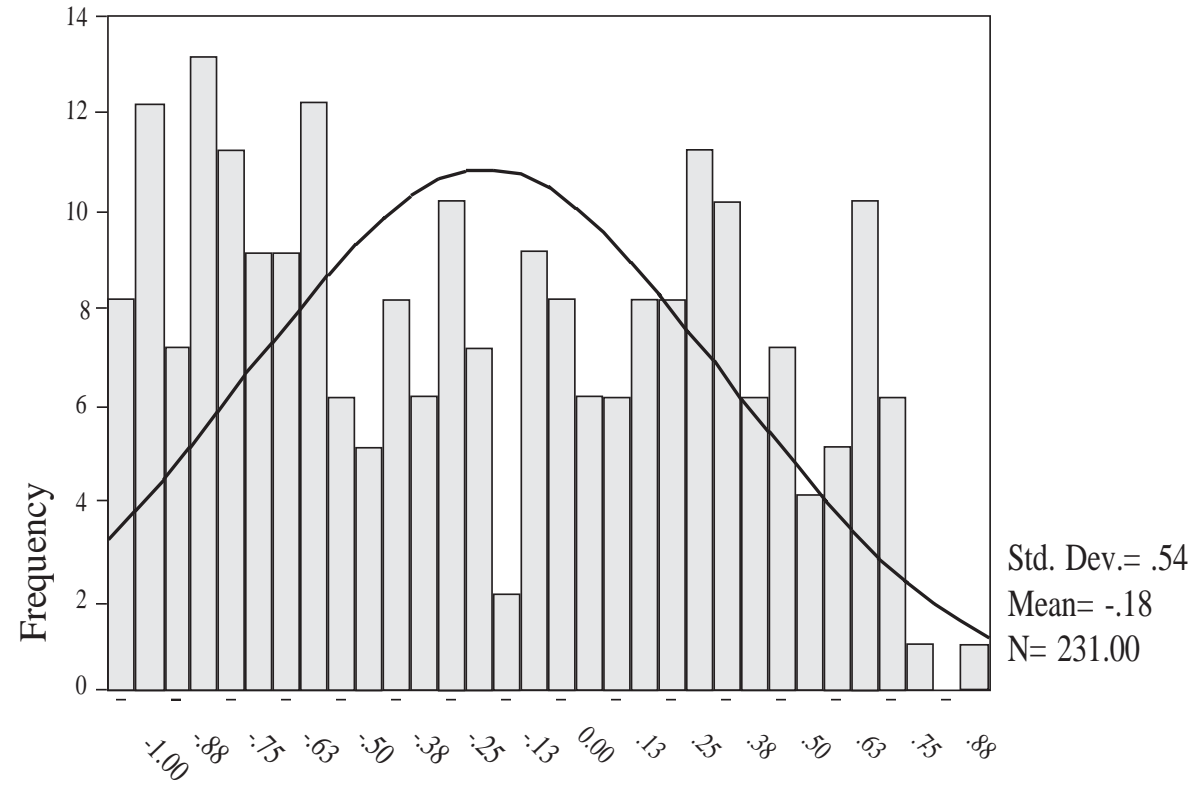


Gadjah Mada International Journal of Business, January - April 2008, Vol. 10, No. 1

Continued from Figure 2: Distribution of Comparative Advantages (China) C_RSCA98

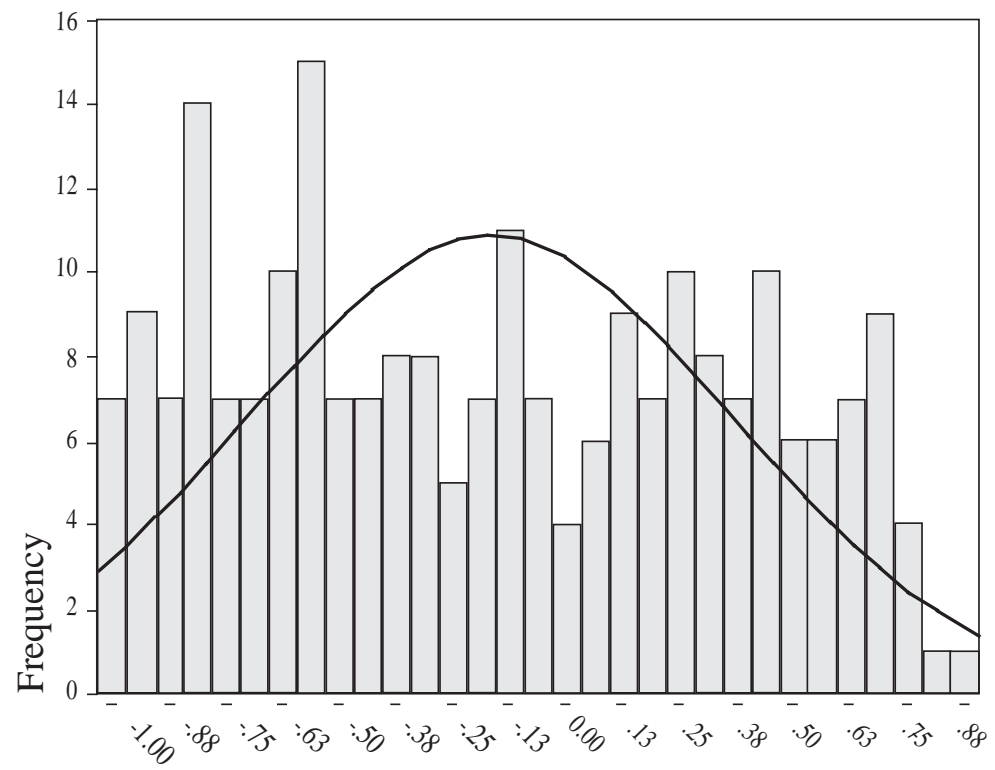

Std. Dev. $=.53$

Mean $=-.16$

$\mathrm{N}=231.00$

C_RSCA03

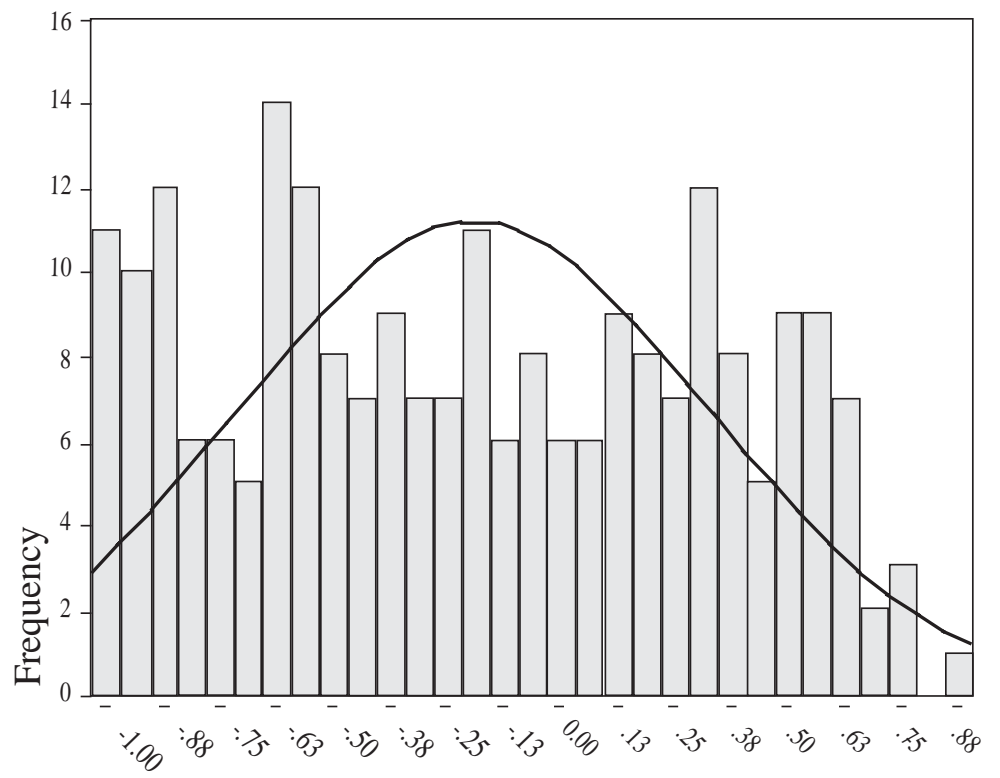

Std. Dev. $=.51$

Mean $=-.19$

$\mathrm{N}=231.00$ 


\section{Tri Widodo-Shifts in Pattern of Specialization}

Continued from Figure 2: Distribution of Comparative Advantages (India)

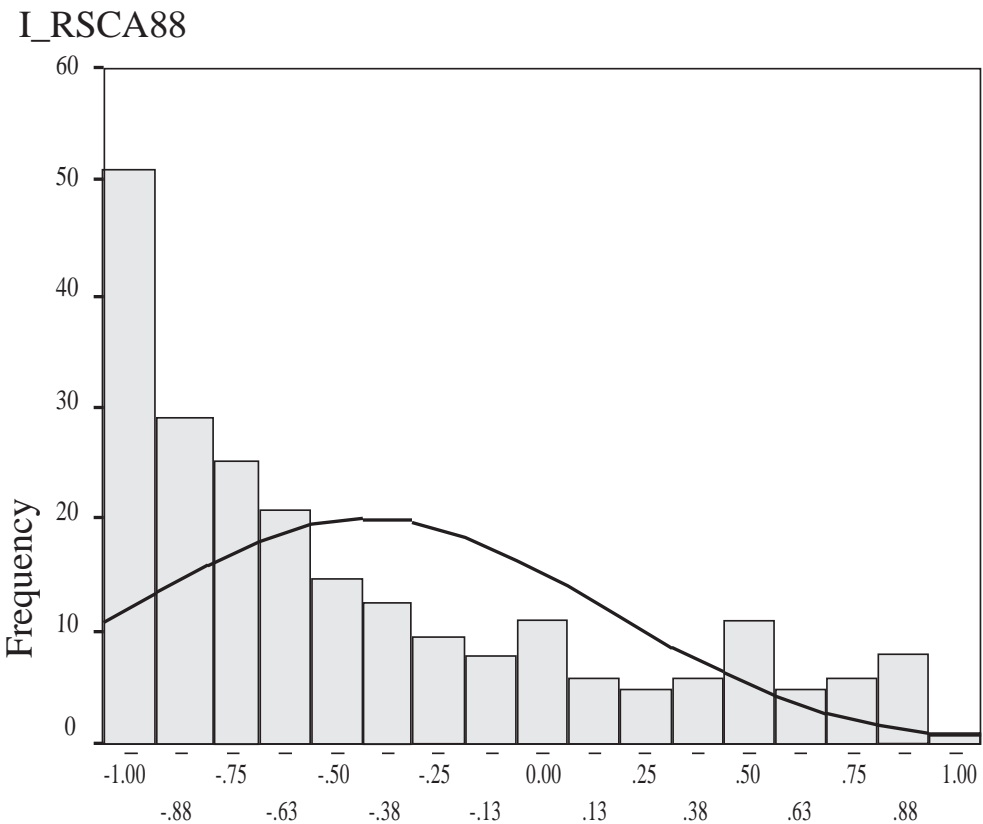

Std. Dev. $=.57$

Mean $=-.43$

$\mathrm{N}=231.00$

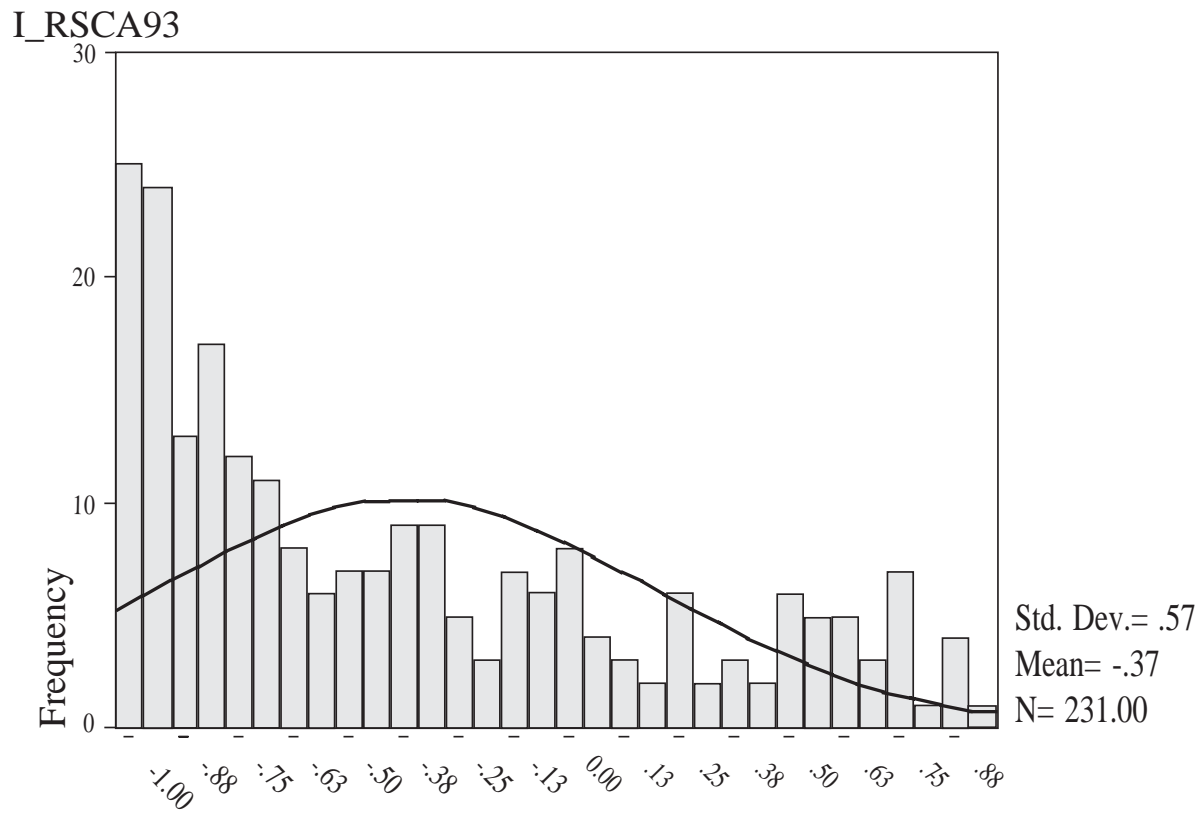


Gadjah Mada International Journal of Business, January - April 2008, Vol. 10, No. 1

\section{Continued from Table 3: Distribution of Comparative Advantages (India)}

I_RSCA98

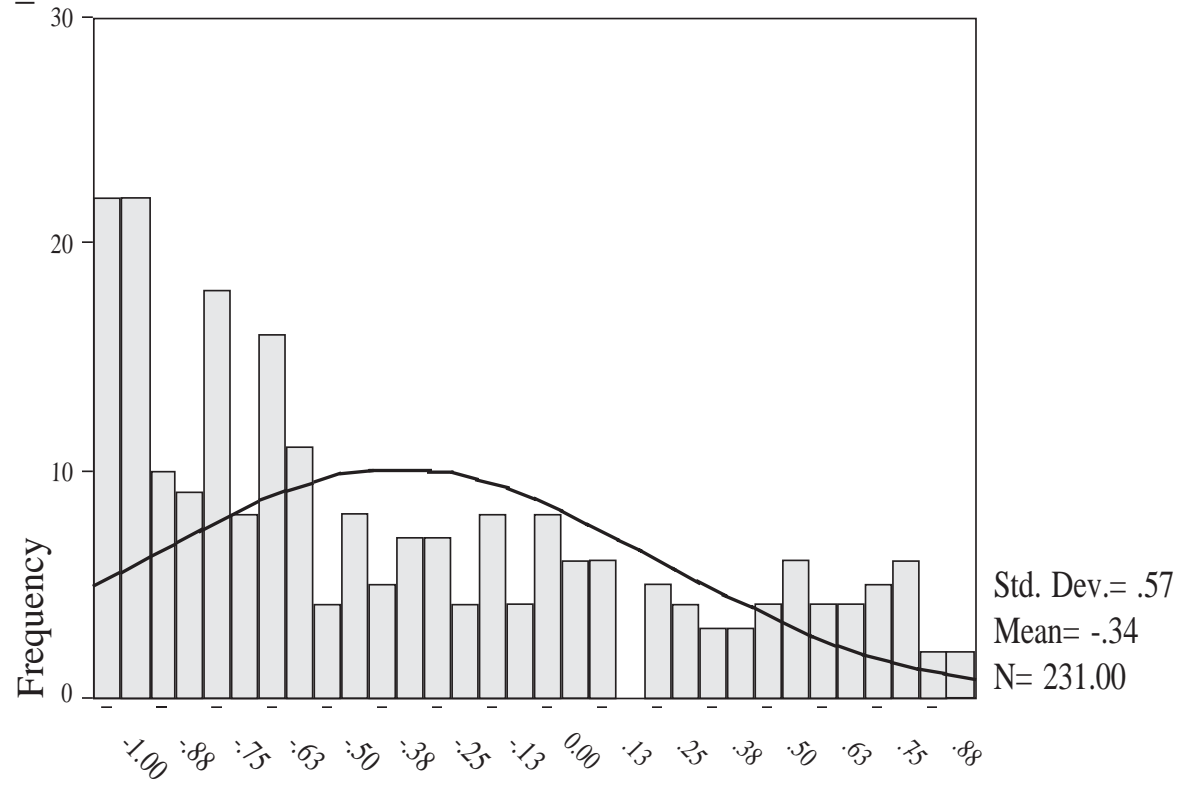

I_RSCA03

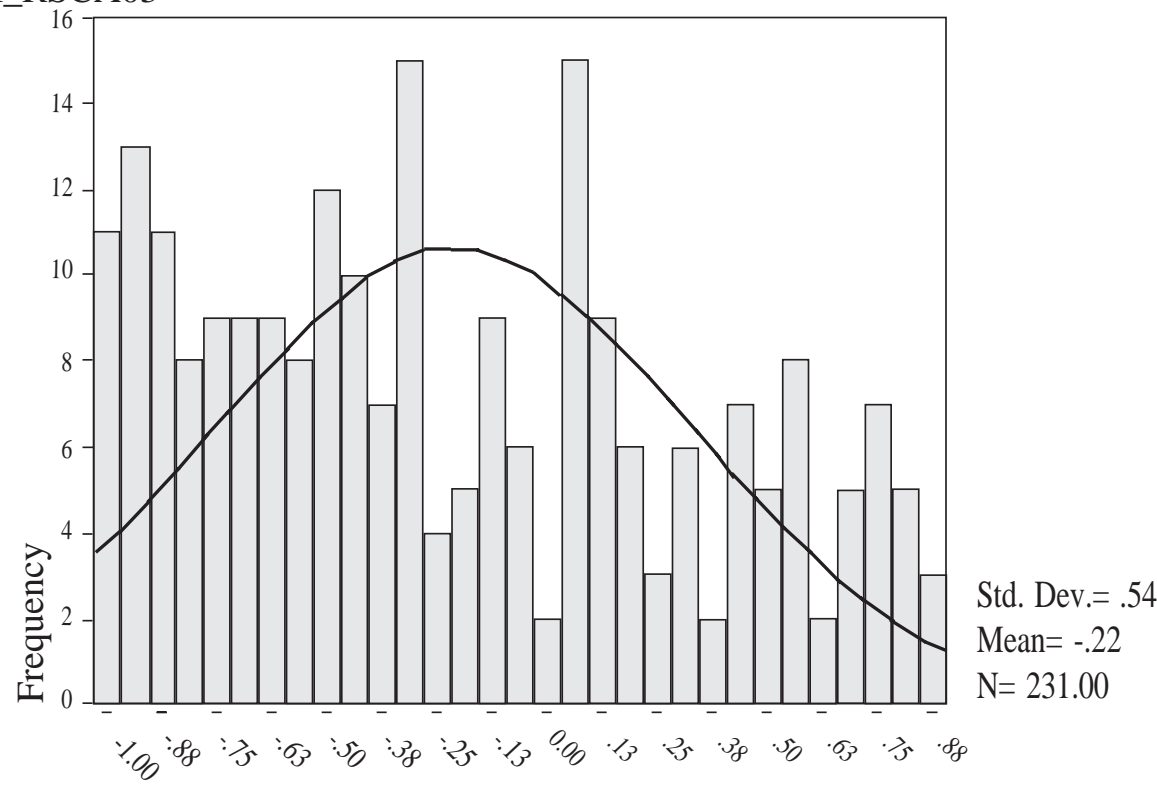

Notes: C_RSCA88, C_RSCA93, C_RSCA98, and C_RSCA2003 denote China's Revealed Comparative Advantage for 1988, 1993, 1999 and 2003, respectively. I_RSCA88, I_RSCA93, I_RSCA98, and I_RSCA2003 denote India's Revealed Comparative Advantage for 1988, 1993, 1999 and 2003, respectively.

Source: the ITSY and UN-COMTRADE (author's calculation). 


\section{Relevance of the Trade Liberalization Evolution}

The shifts in pattern of comparative advantages are very closely related with the evolution of trade liberalization in India and China. The importance of liberalizing trade policies for pro-faster growth of GDP and trade in the case of China and India is clearly understandable. In the late 1970s, the level of protection was high and international trade was centrally controlled. In the case of India's manufacturing sector, for example, Aksoy and Ettori (1992) find that some 210 effective protection rates (ERP) from various sources which are grouped into 16 product categories are generally high (such as: edible oils 85 percent, cotton yarns 52 percent, synthetic textiles 100 percent, heavy chemicals 68 percent, synthetic fibers/resins 162 percent, iron/steel products 72 percent, casting/forging 72 percent, non-electrical machinery 64 percent, electronic and parts 92 percent). Throughout the fastgrowth period, China and India have been more and more opening up their economies and integrating them with the world economies. To some extent, the success of China and India's domestic policies are affected by the policy regimes. China has faster approach in opening up domestic market than that of India.

In 1980s, the China's overall trade regime was more open than that of India. China and India have different paths of liberalization. China takes the form of 'decentralization' of trade i.e. giving independence and right to export and import activities. The number of Foreign Trade Corporations (FTCs, either at the central level or the provincial level) increases dramatically from just 12 FTCs with monopoly rights on trade in 1978, to 800 FTCs in 1985 and to more than 5.000 FTCs with full authority in trade in 1988 (Panagariya 2006). Foreign-invested companies (joint venture or wholly foreign owned) are also given the rights to have their foreign trade. Some policies are established following the decentralization of trade such as revision of the exchange rate trough devaluation, incentive for export, establishment of a system of rebating the value added, custom duties paid on inputs used in exports, and duty drawback. The Special Economic Zones (SEZs) and Open Cities also provide competitive environment for doing business (Das 2006; Srinivasan 2006). All of those trade reforms have significantly affected exports and imports in the late 1980s (as depicted in Figure 3).

The India's basic regime for any product is licensing. In 1979, India established a system that classified products not domestically produced into three categories, i.e. Open General Licensing (OGL), Banned, and Restriction items. Products not in the OGL list are categorized into Banned or Restriction items. Even then, only input not produced at home had been liberalized. India undertakes piecemeal liberalization during the 1980s (Das 2006). It includes elimination of the share of canalized products from 67 
percent in 1980-81 to 27 percent in 1986-87; expansion of OGL from 5 percent in 1980-81 to roughly 30 percent in 1987-88, relaxation of industrial controls, setting exchange rate in the more realistic levels (Lardy 2002).

Some policies introduced to promote export include a passbook scheme for duty free imports for exporters; increase in the business income tax deduction to 4 percent of net foreign exchange realization plus 50 percent (raised to 100 percent in 1988) of the remaining profits from exports; reduction in the interest rate on export credit from 12 to 9.5 percent; faster processing of export credit and duty drawback; upward revision of the rates of Cash Compensatory Support (CCS) for offsetting internal taxes; international Price Reimbursement Scheme for raw materials for all major export sector (i.e. exporters are effectively offered international prices on internationally traded goods even when such inputs are purchased domestically); permission to retain 5-10 percent of foreign exchange receipts for export promotion; duty free capital goods imports for exporters in 'thrust' industry; full remission of excise duties and domestic taxes (Panagariya 2006). All of these policies along with the depreciation of the real exchange rate play an important role in the growth in export, which is observed in the second half of the 1980s as shown by Figure 3.

China and India have pursued their reform and liberalization since 1990s. In comparing the trade regimes of the two countries, China is more open than India in the industrial sector.

Figure 3. Trends in Export and Import: China and India, 1978-2005

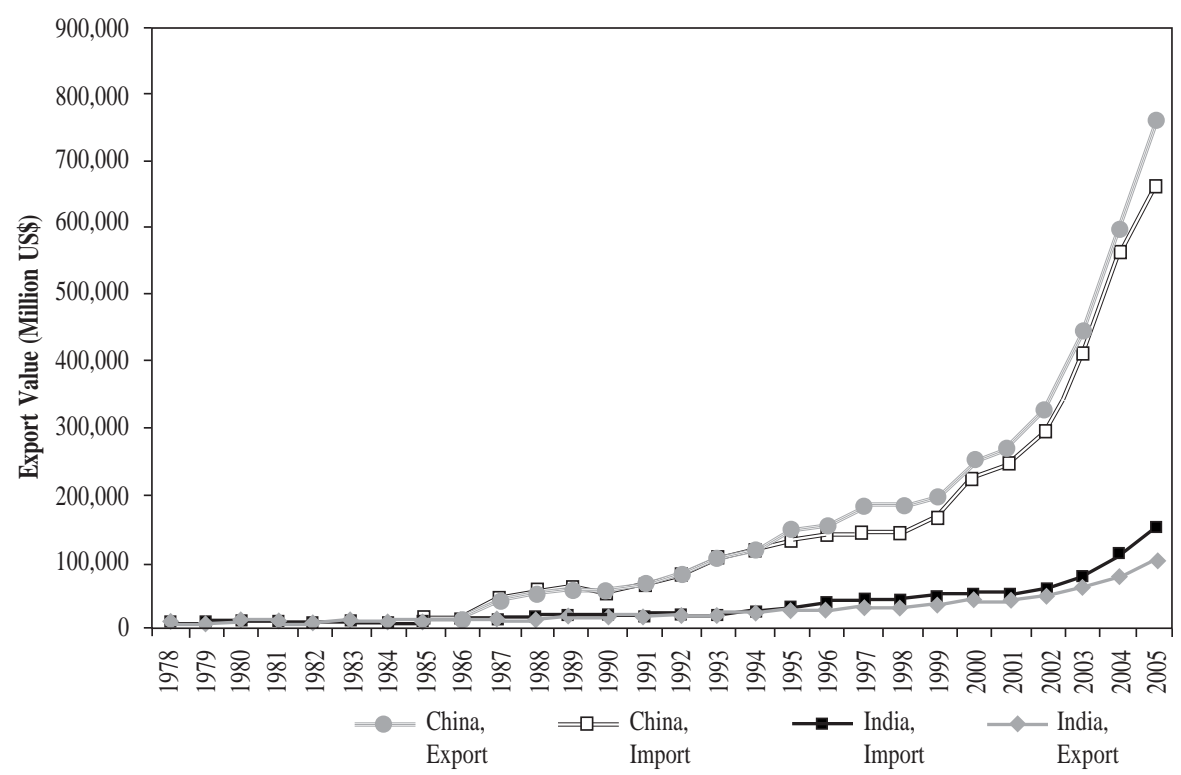

Source: The ITSY and UN-COMTRADE (author's calculation). 
However, the later is gradually catching up. India abandoned the importlicensing regime before China did. In fact, India has abolished licensing on imports of consumer goods. India is nearly license-free and relatively liberal in industrial products. The current tariff rates in India and China are almost relatively similar now. Export and import expansions have tremendously occurred since 1999 as presented by Figure 3. As mentioned in the previous subpart, the overall China's comparative advantage decreased for 1999-2003. A country with a very rapid expansion in exports might frequently experience decrease in the comparative advantage because there are many shifts in the pattern of comparative advantages.

\section{Patterns of Comparative Advantage: Convergence or Divergence}

China and India start their trade liberalization in almost relatively the same period. Different approaches of the trade liberalization have been implemented in both countries. In the beginning of the liberalization, China is more progressive than India. Therefore, it might be believed the India's pattern of comparative advantages is left behind compared with that of China. Table 8 represents the Spearman's rank correlation coefficients between the China's and India's comparative advantages over 19882003. Higher coefficient means higher linear association (similarity or com-

Table 8.Spearman's Rank Correlation Coefficients:

China's and India's Comparative Advantages

\begin{tabular}{|c|c|c|c|c|c|}
\hline \multirow{6}{*}{ 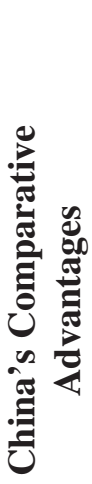 } & & \multicolumn{4}{|c|}{ India's Comparative Advantages } \\
\hline & & 1988 & 1993 & 1998 & 2003 \\
\hline & 1988 & $.428 *$ & $.407 *$ & $.437 *$ & $.360^{*}$ \\
\hline & 1993 & $.348 *$ & $.345^{*}$ & $.369 *$ & $.320 *$ \\
\hline & 1998 & $.310^{*}$ & $.308 *$ & $.358 *$ & $.284^{*}$ \\
\hline & 2003 & $.318^{*}$ & $.278 *$ & $.311^{*}$ & $.221^{*}$ \\
\hline
\end{tabular}

Note: * Correlation is significant at the 0.01 level (2-tailed).

Source: See section 3 (author's calculation). 
Gadjah Mada International Journal of Business, January - April 2008, Vol. 10, No. 1

petition) between the China and India's patterns of comparative advantages. Positive coefficient implies that India is the follower (if it is not being said as competitor) of China. However, in the main diagonal of Table 8 , it shows that the coefficient decreases from 0.428 in 1988 to 0.221 in 2003. It indicates that the similarity level in the pattern of comparative advantage, which also implies competition, between the two countries decrease. China and India exhibit different direction of shifts in the pattern of comparative advantages that are more complement each other.

\section{Concluding Remarks and Future Implications}

This papercomparatively analyzes shifts in the pattern of comparative advantages and discusses the evolution of the trade liberalization in China and India, which cause the shifts. Some conclusions are established. First, there were significant shifts in the patterns of comparative advantages from 19882003. The China's structural shifts are more dynamic than that of India. From the top-exported groups of products, the domination of the manufacturing sector appears in China is evident, but in India it is the natural resource based sector which is obvious. Second, as emerging countries, China and India have significantly increased their comparative advantages and specialization of export. The India's comparative advantage increased steadily and significantly during 1988-2003. In the case of China, it increased during 1988-
1999 but decreased during 1998-2003. The shifts in comparative advantage are closely related with the evolution of trade liberalization. In comparing the trade regimes of the two countries, China is more open than India in industrial products, but the later is steadily catching up. Third, the pattern of India's comparative advantages has positive linear association (similarity or competition) with that of China. However, the similarity level of the pattern of comparative advantages decreases. From 1988-2003, China and India had different direction of shifts in the pattern of comparative advantages that were more complement each other.

As two important hubs of international trade in the Asia region (India in South Asia and China in East Asia), the different shifts in patterns of comparative advantages will bring future complementary relationships among countries in the region. Although the Association of South East Asia Nations (ASEAN) countries (especially Singapore) and Japan are still the dominant trade partners for India, for the last ten years (1995-2005) trade transactions between India and China have increased significantly. The value of India's export to China grew at 167.8 percent and 750.3 percent for periods 1995-2000 and 2000-2005, respectively. Meanwhile, the value of India's import from China grew at 78.7 percent and 578.3 percent for periods 1995-2000 and 2000-2005, respectively. 
The different shifts in the patterns of comparative advantages will also open wider opportunities for future economic cooperation between not only India and China, but also India and other countries in the East Asian region, since the regional intra-trade have increased and there are strong interdependencies (production sharing). The East Asian intra-trade grew at the rates of 22.9 percent and 78.5 percent for the period 1995-2000 and 2000-2005, respectively. The value of
India's export to the region grew at 21.5 percent and 190.2 percent for the period 1995-2000 and 2000-2005, respectively. Meanwhile, the value of India's import from the region grew at 51.8 percent and 205.3 percent for the period 1995-2000 and 2000-2005, respectively. As the center of trade in the South Asia region, theincrease of trade between India and the region could encourage the development of the South Asian Association for Regional Cooperation (SAARC).

\section{References}

Aiginger, K. 1999. Do industrial structures convergence? A survey of the empirical literature on specialization and concentration of industries. Working Paper: 116. Austrian Institute of Economic Research (WIFO) 116, Vienna.

Aksoy, M. A., and F. M. Ettori. 1992. Protection and industrial structure in India. Policy Research Working Paper. The World Bank.

Athukorala, P-C., and N.Yamashita. 2005. Production fragmentation and trade integration: East Asia in global context. Working Paper. Research School of Pacific and Asian Studies (RSPAS), The Australian National University (ANU), Canberra, Australia. http://rspas.anu.edu.au/economics/publish/papers/wp2005/wp-econ-200507.pdf (accessed November 2006).

Balance, R.H., H. Forstner, and T. Murray. 1987. Consistency test of alternative measures of comparative advantage. Review of Economics and Statistics 69 (1): pp. 157-161.

Balassa, B. 1965. Trade liberalization and "revealed" comparative advantage. The Manchester School of Economics and Social Studies 33: 92-123.

Balassa, B. 1979. The changing pattern of comparative advantage in manufactured goods. Review of Economics and Statistics 61: 259-266.

Balassa, B. 1986. Comparative advantage in manufactured goods: a reappraisal. Reviews of Economics and Statistics 68: 315-319.

Batra, A., and Z. Khan. 2005. Revealed comparative advantage: an analysis for India and China. Working Paper No. 168. The Indian Council for Research on International Economic Relations (ICRIER).

Bloom, D. E., D. Caning, David, L. Hu, L. Yuanli, A. Mahal, and W. Yip. 2006. Why has China's economy taken off faster than India's. Paper presented at the 2006 PAN Asia Conference, Stanford University, CA. http://scid.stanford.edu/events/PanAsia/Papers/Bloom.pdf (accessed November 2006). 
Gadjah Mada International Journal of Business, January - April 2008, Vol. 10, No. 1

Das, D. K. 2006. China and India A Tale of Two Economies. New York: Routledge.

Gujarati, D. N. 2000. Basic Econometric. New York: McGraw Hill.

Grubel, H. G., and P. J. Lloyd. 1975. Intra-industry Trade: The Theory and Measurement of International Trade in Differentiated Products. London: The MacMillan Press Ltd.

Grossman, G. M., and E. Helpman. 1991. Trade, knowledge spillovers, and growth. NBER Working Paper No. W3485.

Hinloopen, J., and C. van Marrewijk. 2001. On the empirical distribution of the Balasa index. Weltwirtschaftliches Archiv 134 (1): 1-35.

Hinloopen, J., and C. van Marrewijk. 2004a. Measuring trade dynamic. Mimeo. Tinbergen Institute.

Hinloopen, J., and C. van Marrewijk. 2004b. P-P plots and the Harmonic Mass index: An application to comparative advantage. Mimeo. Tinbergen Institute.

Hinloopen, J., and C. van Marrewijk. 2004c. Dynamic of Chinese comparative advantage. Tinbergen Institute Working Paper TI 2004-034/2.

Isogai T., H. Morishita, and R. Rüffer. 2002. Analysis of intra- and inter-regional trade in East Asia: Comparative advantage structure and dynamic interdependency in trade flows. Working Paper 02-E-1. International Department. Tokyo, Japan: Bank of Tokyo.

James, W. E., and O. Movshuk. 2003. "Comparative advantage in Japan, Korea, and Taiwan between 1980 and 1999: Testing for convergence and implications for closes economic relations”. The Developing Economies XL 1-3: 287-308.

Jones, R. W. 2000. Globalization and the Theory of Input Trade. Cambridge: MIT Press.

Krugman, P. 1991. Increasing return and economic geography. Journal of Political Economy 89: 959-73.

Krugman, P., 1979. Increasing returns, monopolistic competition, and international trade. Journal of International Economics 9: 469-79.

Lardy, N. 2002. Integrating China into the Global Economy. Washington, D.C.: Brookings Institution Press.

Laursen, K. 1998. Revealed comparative advantage and the alternatives as measures of international specialization. DRUID Working Paper No 98-30. Danish Research Unit for Industrial Dynamics (DRUID). http://www.druid.dk/uploads/tx_picturedb/ wp98-30.pdf

Martin, W. and V. Manole, 2004. "China's emergence as the workshop of the world". Working Paper 216 (June 4). Stanford: Stanford University, Stanford Center for International Development.

Ng, F., and A. Yeats. 2003. Major trade trends in East Asia: what their implication for regional cooperation and growth?.Policy Research Working Paper 3084. The World Bank.

Panagariya, A. 2006. India and China: Trade and foreign investment. Paper Presented at 'Pan Asia 2006' Conference. Stanford Center for International Development. http:/ /scid.stanford.edu/events/PanAsia/Papers/Panagariya.pdf(accessed 10 January 2007). 
Tri Widodo-Shifts in Pattern of Specialization

Roland, D. H., 2003. East Asian pattern of comparative advantage. Research Paper Series XX. ADB Institute

Srinivasan, T. N. 2006. China, India and the world economy. Working Paper 286 (July). Stanford Center for International Development, July, http://scid.stanford.edu/pdf/ SCID286.pdf (accessed 10 November 2006).

Todaro, M., and S. Smith. 2006. Economic Development (ed. $9^{\text {th }}$ ). Addison-Wesley series in economics.

Trefler, D. 1995. The case missing trade and other mysteries. American Economic Review 85 (5):1029-46.

United Nations Conference on Trade and Development (UNCTAD). 2005. Trade and Development Report 2005. New York and Geneva.

United Nations (UN) (Various Years: 1985-2004). International Trade Statistics Yearbook. United Nations, Department of Economic and Social Affairs.

United Nations (UN) (Various Years: 1985-2004.) United Nations Commodity Trade Statistics Database. United Nations-Statistics Division, http://comtrade.un.org/db/ (Accessed November 2006).

Urata, S. 2006. A shift from market-driven to institutional-driven regionalization in East Asia. Paper prepared for the 'Conference on Economic Policy Reform in East Asia (May 31-June 3). To be held at Stanford University. http://scid.stanford.edu/events/ PanAsia/Papers/Urata.pdf (accessed 10 November 2006).

World Bank. 2006. World Development Indicators. Washington D.C.: World Bank.

Venables, A. J. 2001. Geography and international inequalities; the impact of new technology. Paper Prepared for ABCDE. World Bank, Washington D. C. [Online; cited on 11 March 2007]. Available from http://www.econ.ox.ac.uk/members/ tony.venables/abcde3.pdf.

World Trade Organization (WTO). 2005. International Trade Statistics. Geneva: World Trade Organization.

Wörz, J. 2005. Dynamic of trade specialization in developed and less developed countries. Emerging Markets Finance and Trade 41: 92-111. 